\title{
Anti-Cancer Activity of Cayratia Auriculata Ethanolic Extracts Against Cancer Cell Line A549 - An In Vitro Analysis
}

\author{
S. Lalitha', D. Anusha ${ }^{2, *}$, Yogeshkumar Murkunde ${ }^{3}$, Viji Devanand ${ }^{4}$, K.Maheshkumar ${ }^{5}$
}

S. Lalitha', D. Anusha ${ }^{2, *}$, Yogeshkumar Murkunde ${ }^{3}$, Viji Devanand $^{4}$, K.Maheshkumar

'Demonstrator, Department of Physiology, Sri Ramachandra Medical College and Research Institute, Sri Ramachandra Institute of Higher Education and Research centre (SRIHER), Porur, Chennai-600116, INDIA.

2Professor, Department of Pharmacology, Sri Ramachandra Medical College and Research Institute, Sri Ramachandra Institute of Higher Education and Research centre (SRIHER),

Porur, Chennai-600116, INDIA.

${ }^{3}$ Test Head Animal House/Facility

Management (CEFT), Sri Ramachandra Medical College and Research Institute, Sri Ramachandra Institute of Higher Education and Research centre (SRIHER), Porur, Chennai -600116, INDIA.

${ }^{4} \mathrm{HOD} \&$ Professor, Department of Physiology, Stanley Medical College\& Hospital,

Royapuram, Chennai-600001, INDIA. ${ }^{5}$ Assistant Medical officer/Lecture Grade II,

Department of Biochemistry and Physiology, Government Yoga and Naturopathy Medical college and Hospital, Chennai -600106, INDIA.

\section{Correspondence}

\section{Dr. D. Anusha}

Professor, Department of Pharmacology,

Sri Ramachandra Medical College and

Research Institute, Sri Ramachandra

Institute of Higher Education and Research

(SRIHER), Porur, Chennai - 6000116,

INDIA.

Phone no: 9884313112

E-mail: drdanusha@gmail.com

History

- Submission Date: 28-10-2020;

- Review completed: 14-11-2020;

- Accepted Date: 30-12-2020

DOI : 10.5530/pj.2021.13.62

Article Available online

http://www.phcogj.com/v13/i2

\section{Copyright}

(C) 2021 Phcogj.Com. This is an openaccess article distributed under the terms of the Creative Commons Attribution 4.0 International license.

\section{ABSTRACT}

Background: The purpose of this study was to evaluate the anticancer activity of ethanolic cayratia auriculata extracts using the A549 cell line MTT assay. Materials and Methods: Using Soxhlet apparatus, ethanolic extracts from cayratia auriculata were prepared. The cancer cells were exposed to $12.5,25,50,100,150,200 \mu \mathrm{g} / \mathrm{mL}$ and incubated for $24 \mathrm{~h}$ at different concentrations. Compared with control, C. auriculata exhibited a cytotoxic effect. Results: At 150 and $200 \mu \mathrm{g} / \mathrm{ml}$ concentrations, with 61 percent and 73.7 percent respectively, the highest cytotoxicity was identified. The findings show that cytotoxicity is directly proportionate to the concentration of the extract. IC50 of the ethanolic extract value of $C$. auriculata was found to be $102.9 \mu \mathrm{g} / \mathrm{ml}$ against the $\mathrm{A} 549$ cell line. Conclusion: In the present analysis, C.auriculata ethanolic extract was shown to be a strong suppressant for cell division and proliferation. As for anti-tumor medicine, it can be a new source and can be effectively used as an immunological anti-malignant compound.

Key words: Activity against cancer, Cell line cancer, Ethanol extract, MTT assay.

\section{BACKGROUND}

Lung cancer is the world's leading cause of death and it has been noted that 7.6 million deaths were recorded in 2008. Death rates have been forecast to rise by more than 11 million in $2030^{1}$. Usually, 80 percent of cases of histologically non-small cell lung cancer are a big health issue ${ }^{2}$. Due to the high incidence rate, rapid development and poor prognosis, lung cancer-related deaths have been the leading cause $e^{3}$. With an average survival rate of around 15 percent, it has become a burden worldwide 4 . There are more medications available today to manage lung cancer. Chemotherapy is the routine treatment for lung cancer, but it does have several side effects that also affect the quality of life of patients ${ }^{5}$. It is still deficient, considering the numerous treatment methods available to avoid these side effects ${ }^{6,7}$. Therefore, new drugs or innovative ways to cure or avoid this global warming disease are being pursued. Several medicinal plants have been used globally for the treatment of different forms of cancer ${ }^{8}$. Conventional medicine with its low toxicity and side effects has the ability to treat anticancer activity. According to the WHO study, in contrast to modern medicine, $80 \%$ of the world 's population relies on conventional medicine because of its less side effects, cost effectiveness, protection, and effective prognosis9. Even today, several tribal groups are practicing herbal medicine to cure various diseases ${ }^{10}$. The medicinal plant belonging to the Vitaceae family is Cayratia auriculata. Cayratia auriculata (Roxb.) gamble is a synonym for Cyphostemma auriculatum (Roxb), a climber well cultivated in dry evergreen to dry deciduous forests and well distributed in Andhra Pradesh, Tamilnadu, and Maharashtra ${ }^{11,12}$. For several diseases, cayratia auriculata has been used as herbal medicine. The leaf is the most important part of the plant as it has potent ethno-medicinal properties. It is used in the treatment of snake bite, dog bite, abscess, rheumatism, cardiovascular disease, tumours, and also in the treatment of cold, cough, worm infestation ${ }^{13}$. The genus is also used for bloody dysentery and diarrhoea in veterinary medicine. Based on previous studies, a study on the cytotoxic activity of $C$. auriculata extract is still limited to lung cancer. The present study was therefore conducted to determine the anticancer and cytotoxicity potential of Cayratia auriculata unrefined ethanolic leaf extract.

\section{MATERIALS AND METHODS}

Plant content processing and authentication

Cayratia auriculata was collected in November 2018 from the botanical garden of Andhra University, Visakhapatnam, Andhra Pradesh. The plant content has been identified and approved by Dr. S.B. Padal, Associate Professor, Department of Botany, Visakhapatnam, Andhra University.

\section{Preparation of extracts for plants}

Fresh leaves of Cayratia auriculata were washed in flowing tap water, dried in the shade and powdered. Approximately $75 \mathrm{~g}$ of coarsely powdered plant materials $(75 \mathrm{~g} / 250 \mathrm{~mL})$ were extracted for 10 to 12 hours in a soxhlet extractor. The desired compounds were condensed in the distillation flask after several cycles, the extracts were finally collected, then condensed and finally dried to a constant weight. Before usage, dried extracts were stored at $20^{\circ} \mathrm{C}$. In an in vitro trial, this extract was used. 


\section{Reagents}

The Minimum Critical Medium reagents were supplied by HiMedia Lab systems. Cistron Labs supplied foetal bovine serum (FBS). Reagents like 3-[4,5-dimethylthiazol-2-yl]- 2,5-diphenyl tetrazolium bromide (MTT), dimethyl sulfoxide (DMSO), trypsin-EDTA, phosphate buffered saline (PBS) were supplied by Sisco Research Laboratory Chemicals, Mumbai. From Sigma-Aldrich, Mumbai, all the other chemicals and reagents were purchased. MTT (3-(4,5-dimethylthiazol2yl)-2,5-diphenyl tetrazolium bromide) stock solution $5 \mathrm{mg} / \mathrm{ml}$ was prepared and wrapped with aluminium foil as it is light-sensitive. $5 \mathrm{mg}$ of extract was taken and suspended in $1 \mathrm{ml}$ of water. Solutions with various concentrations $(200 \mu \mathrm{g} / \mathrm{ml}, 150 \mu \mathrm{g} / \mathrm{ml}, 100 \mu \mathrm{g} / \mathrm{ml}, 50 \mu \mathrm{g} / \mathrm{ml}, 25$ $\mu \mathrm{g} / \mathrm{ml}$ and $12.5 \mu \mathrm{g} / \mathrm{ml}$ ) were prepared from the stock solution ${ }^{14}$.

\section{Procedure of MTT assay proceedings}

In lung cancer, the effect of the drug was tested against the cell line (A549) by MTT assay according to the standard procedure ${ }^{15}$. The cells were seeded in 96-well micro plates (1x106 cells / well) and incubated in a $5 \% \mathrm{CO} 2$ incubator at $37^{\circ} \mathrm{C}$ for 24 hours and allowed $80 \%$ confluence to expand. The medium was then substituted and the cells were treated with drugs at varying concentrations, such as $12.5,25,50,100,150,200$ $\mu \mathrm{g} / \mathrm{mL}$ and were incubated for 24 hours. The cells were then washed and applied to each well with phosphate-buffer saline (PBS, pH-7.4) and $20 \mu \mathrm{L}$ (MTT) solution $(5 \mathrm{mg} / \mathrm{mL}$ in PBS). The plates were then placed for an additional $2-4 \mathrm{~h}$ at $37 \mathrm{oC}$ in the dark. In $100 \mu \mathrm{L}$ DMSO the formazan crystals were dissolved and the absorbance at $570 \mathrm{~nm}$ was spectrometrically read. The morphological changes of the untreated (control) and treated cells were observed and photographed after 24 $\mathrm{h}$ under a bright field microscope. The concentration required for $50 \%$ inhibition (IC50) was calculated and graphically determined. The cell viability percentage was expressed as a formula.

\section{Calculation:}

$\%$ cell viability $=$ O.D value of treated cells $\times 100$

O.D value of cell control

$\%$ inhibition $=100-\%$ viability

Graphs are plotted using the $\mathrm{X}$-axis sample concentration and the percentage of Y-axis cell viability. In each experiment, sample control and cell control were used to compare the full assessments of cell viability. To understand the biological pharmacological characteristics of a chemotherapeutic agent, the determination of a half maximum inhibitory concentration (IC50) is essential ${ }^{16}$.

\section{STATISTICAL ANALYSIS}

Cell viability data were analysed using one-way ANOVA followed by multiple comparison tests by Dennett with the same sample size using SPSS 17.0.0. The difference was significant when $\mathrm{P}<0.005$ was assessed.

\section{RESULTS}

Table 1 tabulates the test concentration and the corresponding percentage of cell growth inhibition. C. Compared with control, auriculata exhibited a cytotoxic effect. At 150 and $200 \mu \mathrm{g} / \mathrm{ml}$ concentrations, with 61 percent and 73.7 percent, respectively, the highest cytotoxicity was observed. The findings show that cytotoxicity is directly proportionate to the concentration of the extract. Price IC50 of methanolic extract C. auriculata was found to be $102.9 \mu \mathrm{g} / \mathrm{ml}$ versus the A549 cell line. Morphological differences were observed in the untreated (control) and treated cells after $24 \mathrm{~h}$ under a bright field microscope (Figure 1).

\section{Table 1: Cytotoxic activity of C. auriculata leaf extracts against A549 cell line.}

\begin{tabular}{|c|c|c|c|c|c|c|}
\hline Concentration ( $\mu \mathrm{g} / \mathrm{ml})$ & OD 1 & OD 2 & OD 3 & Mean & $\%$ viability & $\%$ inhibition \\
\hline Control & 0.943 & 0.941 & 0.938 & 0.941 & 100.000 & 0.000 \\
\hline 12.5 & 0.931 & 0.928 & 0.934 & 0.931 & 98.972 & 1.028 \\
\hline 25 & 0.773 & 0.776 & 0.771 & 0.773 & 82.211 & 17.789 \\
\hline 50 & 0.645 & 0.642 & 0.647 & 0.645 & 68.533 & 31.467 \\
\hline 100 & 0.526 & 0.530 & 0.529 & 0.528 & 56.166 & 43.834 \\
\hline 150 & 0.367 & 0.364 & 0.369 & 0.367 & 38.979 & 61.021 \\
\hline 200 & 0.244 & 0.248 & 0.251 & 0.248 & 26.329 & 73.671 \\
\hline
\end{tabular}

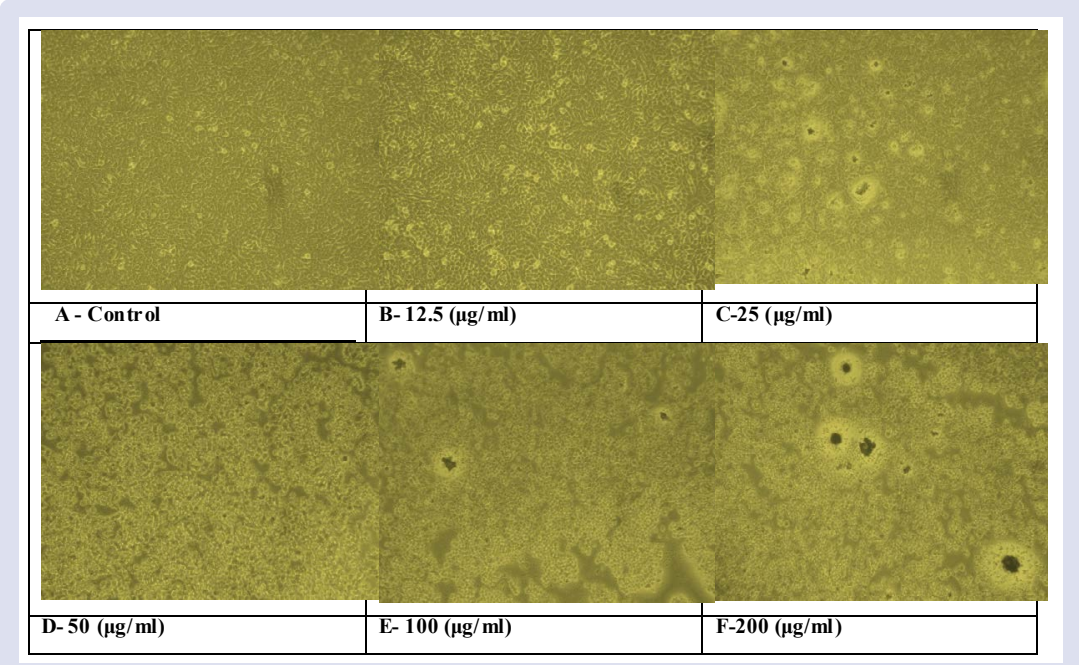

Figure 1: Morphological changes in cells of A549 after treatment with ethanol extracts of C. auriculata leaf extracts. 


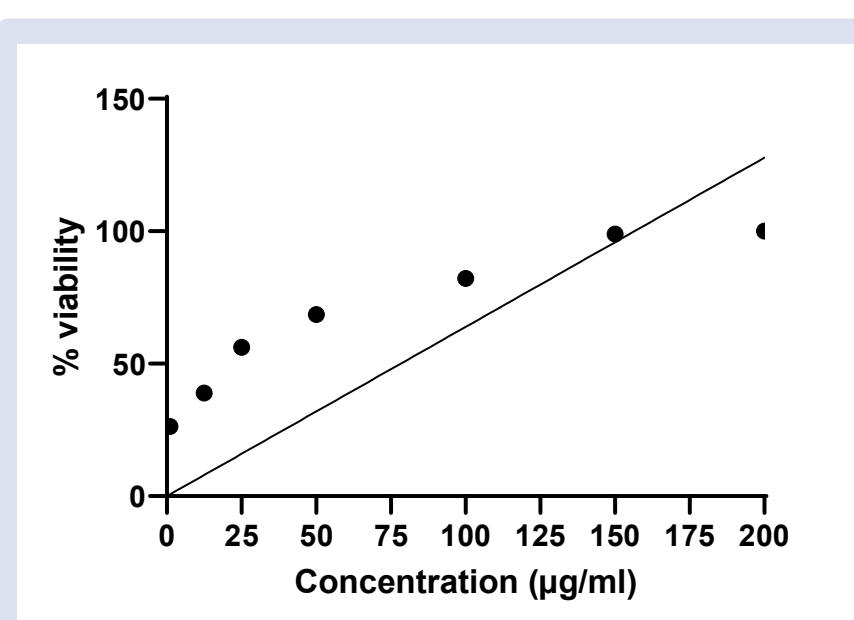

Figure 2: Cell viability after treatment with plant extract on A549 malignant cells.

\section{DISCUSSION}

The key origins of medicines are plant-based herbal extracts. Many herbal extracts and distilled flavonoids have been developed to become medicinal drugs in clinical practise and are used therapeutically in medicine. To evaluate the cytotoxic activity of $C$. auriculata ethanol extracts, the MTT (3-(4, 5-dimethylthiazole-2-il)-2,5diphenyltetrazolium bromide) assay method was used. This technique has been widely used to assess the extract's cytotoxic activity at various concentrations ${ }^{17}$. The basic concept of the method is that every living cell has mitochondrial activity, so the greater the activity, the greater the number of living cells ${ }^{18}$. A cellular reductase enzyme exists in mitochondria that can transform the tetrazolium compound in the MTT reagent into the crystal of purple formazan. The effect of the extract's cytotoxic activity is apparent when the tetrazolium compound 's original yellow colour does not change to purple, suggesting low mitochondrial activity. The lower the activity of the mitochondria, the lower the volume of living cells. Usage of the ELISA reader to read the absorption of the sample at $595 \mathrm{~nm}^{17}$. The MTT assay uses the IC50value as a parameter for the interpretation of cytotoxic activity. IC50 is the amount of concentration of the extract that can suppress the cancer cells' 50 percent activity. The relationship between cytotoxic activity and the IC50 value is inversely proportional, so the higher cytotoxic activity is indicated by the lower IC50 value.

According to the IC50 value, anticancer activity can be categorised into four groups: IC50 $<20 \mu \mathrm{g} / \mathrm{mL}$ is categorised as active; IC50: 20-100 $\mu \mathrm{g}$ / $\mathrm{mL}$ is classified as moderately active; IC50: $100-1000 \mu \mathrm{g} / \mathrm{mL}$ is classified as weakly active; and IC50 $>1000 \mu \mathrm{g} / \mathrm{mL}$ is classified as inactive ${ }^{19}$. In present study, we have found that value of methanol extract of $\mathrm{C}$. auriculata showed IC50 around $102 \mu \mathrm{g} / \mathrm{mL}$ range, which means that C. auriculata extracts are weakly active in inhibiting A549 lung cancer cells activity. Subsequently, C. auriculata extracts, as a natural anticancer agent, may be further developed. As for anti-tumor medicine, it can be a new source and can be effectively used as an immunological antimalignant compound. The preliminary phytochemical screening using chemical methods conducted on the ethanolic extract revealed the presence of various phytochemicals like flavonoids, phenols, coumarin, saponins, tannins, terpenoids, steroids and glycosides. The existence of flavonoids can be responsible for the anticancer property.

\section{CONCLUSION}

In the current research, C.auriculata ethanolic extract was shown to be a strong suppressant for cell division and proliferation. This anticancer activity may be due to the presence of glycosides and flavonoids. Further studies are required to conclude the actual phytoconstituents and underlying mechanisms responsible for the anticancer property.

\section{ACKNOWLEDGEMENT}

We are thankful to management of SRIHER for all the encouragement and support.

\section{CONFLICTS OF INTEREST}

The author declares no competing interest.

\section{REFERENCES}

1. Ferlay J. shin HR, bray F, Forman D, mathers C, Parkin Dm. Cancer Incidence and Mortality Worldwide: IARC CancerBase. 2008(10).

2. Mathur P, Sathishkumar K, Chaturvedi M. Cancer Statistics, 2020: Report From National Cancer Registry Programme, India. JCO Global Oncology. 2020;6:1063-75.

3. Chandra S, Mohan A, Guleria R, Singh V, Yadav P. Delays during the diagnostic evaluation and treatment of lung cancer. Asian Pac J Cancer Prev. 2009;10(3):453-6.

4. Organization WH. World health statistics 2010. World Health Organization; 2010.

5. Wei $Y, X u Y$, Han $X$. Anti-cancer effects of dioscin on three kinds of human lung cancer cell lines through inducing DNA damage and activating mitochondrial signal pathway. Food and chemical toxicology. 2013;59:118-28.

6. Sun CC, Bodurka DC, Weaver CB. Rankings and symptom assessments of side effects from chemotherapy: insights from experienced patients with ovarian cancer. Supportive Care in Cancer. 2005;13(4):219-27.

7. Akin S, Can G, Aydiner A, Ozdilli K, Durna Z. Quality of life, symptom experience and distress of lung cancer patients undergoing chemotherapy. European journal of oncology nursing. 2010;14(5):4009.

8. Yates JS, Mustian KM, Morrow GR Prevalence of complementary and alternative medicine use in cancer patients during treatment. Supportive care in cancer. 2005;13(10):806-11.

9. Kong J-M, Goh N-K, Chia L-S, Chia T-F. Recent advances in traditional plant drugs and orchids. Acta Pharmacologica Sinica. 2003;24(1):7-21.

10. Mahishi P, Srinivasa B, Shivanna M. Medicinal plant wealth of local communities in some villages in Shimoga District of Karnataka, India. Journal of Ethnopharmacology. 2005;98(3):307-12

11. Naidu MT, Kumar OA, Venkaiah M. Taxonomic diversity of lianas in tropical forests of Northern Eastern Ghats of Andhra Pradesh, India. Notulae Scientia Biologicae. 2014;6(1):59-65.

12. Perumal PC, Sowmya S, Velmurugan D, Sivaraman T, Gopalakrishnan VK. Assessment of dual inhibitory activity of epifriedelanol isolated from Cayratia trifolia against ovarian cancer. Bangladesh Journal of Pharmacology. 2016;11(2):545-551.

13. Trias-Blasi A, Chayamarit K, Parnell J. Cyphostemma auriculatum (Roxb.) P. Singh \& BV Shetty (Vitaceae): Typification and a new generic record confirmed for Thailand. Kew Bulletin. 2015;70(2):20.

14. Bahuguna A, Khan I, Bajpai VK, Kang SC. MTT assay to evaluate the cytotoxic potential of a drug. Bangladesh Journal of Pharmacology. 2017;12(2):Online: Apr 8-2017.

15. Mossman B, Light W, Wei E. Asbestos: mechanisms of toxicity and carcinogenicity in the respiratory tract. Annual Review of Pharmacology and Toxicology. 1983;23(1):595-615.

16. He Y, Zhu Q, Chen M. The changing $50 \%$ inhibitory concentration (IC50) of cisplatin: A pilot study on the artifacts of the MTT assay and the precise measurement of density-dependent chemoresistance in ovarian cancer. Oncotarget. 2016;7(43):70803. 
17. Franchi GC, Moraes CS, Toreti VC, Daugsch A, Nowill AE, Park YK. Comparison of effects of the ethanolic extracts of Brazilian propolis on human leukemic cells as assessed with the MTT assay. Evidencebased complementary and alternative medicine. 2012;2012.
18. Van Meerloo J, Kaspers GJ, Cloos J. Cell sensitivity assays: the MTT assay. Cancer cell culture: Springer; 2011:237-45.

19. Fithrotunnisa Q, Arsianti A, Kurniawan G, Qorina F, Tejaputri NA, Azizah NN. In Vitro Cytotoxicity of Hibiscus sabdariffa Linn Extracts on A549 Lung Cancer Cell Line. Pharmacognosy Journal. 2020;12(1).

\section{GRAPHICAL ABSTRACT}

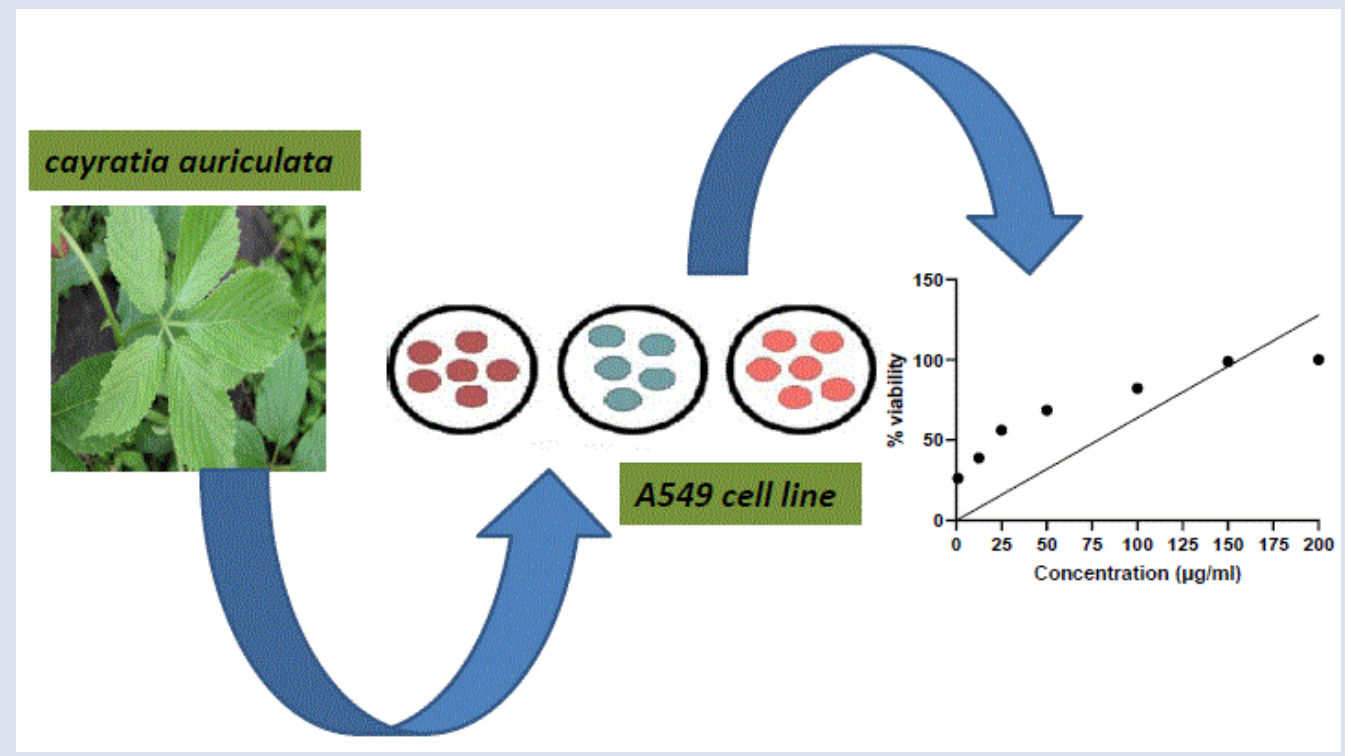

\section{ABOUT AUTHORS}

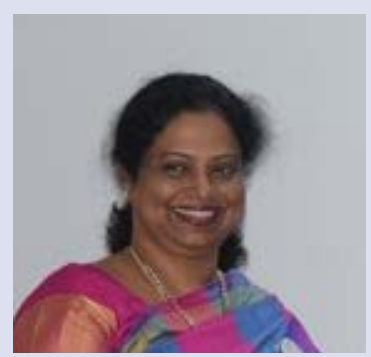

\section{Dr. Viji Devanand}

Dr Viji Devanand completed MBBS from MS Ramaiah Medical College, Bangalore and MD from Madras Medical College. Currently working as Professor and Head of the department of physiology at Stanley Medical College. She also the president of Association of Physiologists Tamilnadu. She have published many research papers in various national and international journals and second author for a textbook and ultra-short note in physiology.

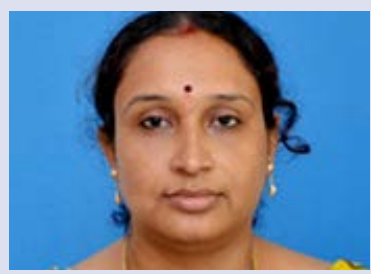

\section{DR. D. Anusha,}

Dr Anusha completed MBBS from IRT Perundurai Medical College and Research Centre, Tamilnadu Dr.MGR Medical University and MD from Sri Ramachandra Medical College. Presently working as Professor in the department of pharmacology at Sri Ramachandra Institute of Higher Education and Research, Chennai. She also part of many ongoing drug trails. She is guiding many UG, PG \& PhD scholars (ICMR). She has published many national \& international journals (Eleven research publication in areas like clinical pharmacology, and invitro studies in indexed journals). 


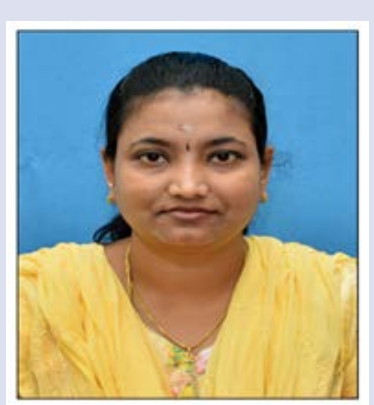

\section{Mrs. S. Lalitha}

Mrs Lalitha completed B.sc allied health science from Ramachandra medical college \& M.Sc Physiology from SRM medical college. Working as Tutor in department of physiology at SRMC\&RI and pursing $\mathrm{Ph}$.D in SRMC. She has published many research papers in various national and international journals. Research areas of interest are Zebrafish and cognitive functions.

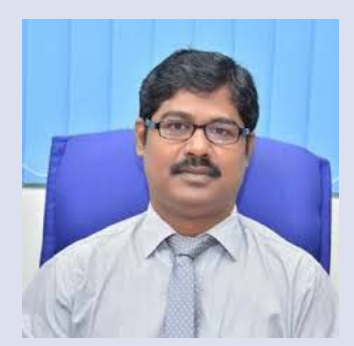

\section{Dr. Yogeshkumar Murkunde}

Dr. Yogeshkumar Murkunde working as the head of the department, toxicology and animal house at Sri Ramachandra Institute of Higher Education and Research. He also part of many ongoing clinical research trials. He is a member of the animal ethics committee. He guiding many PhD students and have many publications in national and international journals.

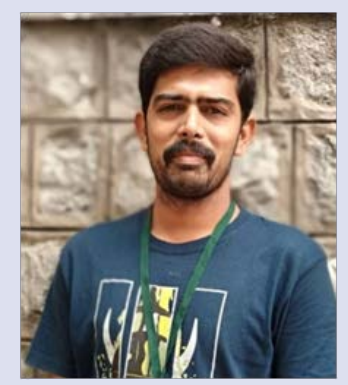

\section{DR. K. Maheshkumar}

Dr. K. Maheshkumar is an Assistant Medical officer at the Government Yoga and Naturopathy Medical College and Hospital, The Tamilnadu Dr. MGR Medical University, Chennai. He is the first Yoga and Naturopathy Medicine doctor successfully completed Ph.D in Faculty of Medicine (Sri Ramachandra Medical College and Research Institute, Chennai). He is also actively involved in the validation of new devices developed in the field of neurophysiology and cognitive science. Dr. K. Maheshkumar has received many awards for his excellence in the academic and research field. He has published more than 60 articles in various national and international journals with 155 citations.

Cite this article: Lalitha S, Anusha D, Murkunde Y, Devanand V, Maheshkumar K. Anti-Cancer Activity of Cayratia Auriculata Ethanolic Extracts Against Cancer Cell Line A549 - An In Vitro Analysis. Pharmacog J. 2021;13(2): 495-9. 